\title{
Időnként semmi sem az, aminek látszik - A klasszifikáció jelentősége a cukorbetegség kezelésében négy eset kapcsán
}

\author{
Kempler Miklós dr., ${ }^{(1)}$ Baló Tímea dr., ${ }^{(1)}$ Varga Éva dr., ${ }^{(1)}$ Barkai László József dr., ${ }^{(1)}$ \\ Körner Anna dr., ${ }^{(2)}$ Pánczél Pál dr., ${ }^{(1)}$ Hosszúfalusi Nóra dr. ${ }^{(1)}$
}

\begin{abstract}
Osszefoglalás
A szerzök a cikkben a diabetes mellitus klasszifikációjának jelentöségét mutatják be négy eset kapcsán, ahol a cukorbetegség típusának pontos meghatározása a korábban megkezdett kezelést nagymértékben befolyásolta. Hangsúlyozzák, hogy olykor a klinikai kép önmagában a klasszifikációhoz nem elégséges, söt akár félrevezetö is lehet. llyenkor a plazmaC-peptid mérése és a szigetsejt elleni autoantitest meghatározása elengedhetetlen segitséget jelent. A bemutatott esetek kapcsán levonják a tanulságokat, és sorra veszik a lépéseket, amelyek az adott diagnózishoz vezettek.

- Kulcsszavak: klasszifikáció, 1-es típusú diabetes, 2-es típusú diabetes, MODY, endocrinopathia

\section{Sometimes nothing is what is seems - Importance of classification in treatment of diabetes through four case reports}

Summary: In this article the authors discuss the importance of classification of diabetes mellitus through four case reports, where the proper classification has induced significant changes in the previous antidiabetic therapy. Sometimes besides the clinical symptoms, fasting C-peptide and the islet cell specific autoantibody titer need to be considered for the precise diagnosis and correct treatment. Each case report is followed by a brief summary of edifications and the steps that led to precise diagnosis.

Keywords: classification, type 1 diabetes mellitus, type 2 diabetes mellitus, MODY, endocrinopathies
\end{abstract}

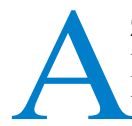
z orvosi kezelés akkor lehet igazán hatékony, ha pontos diagnózison alapul. $\mathrm{Cu}$ korbetegségben a diagnózis a vércukorszint alapján születik, függetlenül attól, hogy mi vezet a vércukor emelkedéséhez. Az alkalmazott kezelés egyrészt függ a vércukoremelkedés mértékétől, azaz az aktuális anyagcserehelyzettől, másrészt a diabetes mellitus típusától. Az Egészségügyi Világszervezet (WHO) 1998-99-ben fogadta el és tette közzé a diabetes mellitus - lényegében napjainkban is érvényben lévő - osztályozását. ${ }^{1,2}$ Míg a korábbi klasszifikáció a cukorbetegség klinikai tüneteit, a beteg életkorát (a diagnózis felállításakor) és a kezelés módját vette alapul, addig ez az osztályozás etiológiai alapon, a diabetes kialakulásához vezető - olykor csak részben ismert - patomechanizmust figyelembe véve jött létre. Ez a klasszifikáció az irányadó a hazai, 2017-ben kiadott Egészségügyi Szakmai Irányelv szerint is (1. táblázat). ${ }^{3}$ A diabetes típusa alapvetően befolyásolja a hosszú távú antiglykaemiás kezelést: autoimmun eredetű 1-es típusú diabetes mellitus (T1DM) esetén/gyanújakor inzulinkezelés alkalmazandó; 2-es típusú cukorbetegségben (T2DM) számos, részben merőben új kezelési lehetőség közül választhatunk, ezek egyike csak az inzulinkezelés; míg az ismert eredetű cukorbetegségben (egyéb speciális típusok alcsoport) lehetőségünk van a diabetes oki kezelésére is. Ami 
1. táblázat. A szénhidrátanyagcsere-zavarok etiológiai klasszifikációja $(W H O, 2006)^{2}$

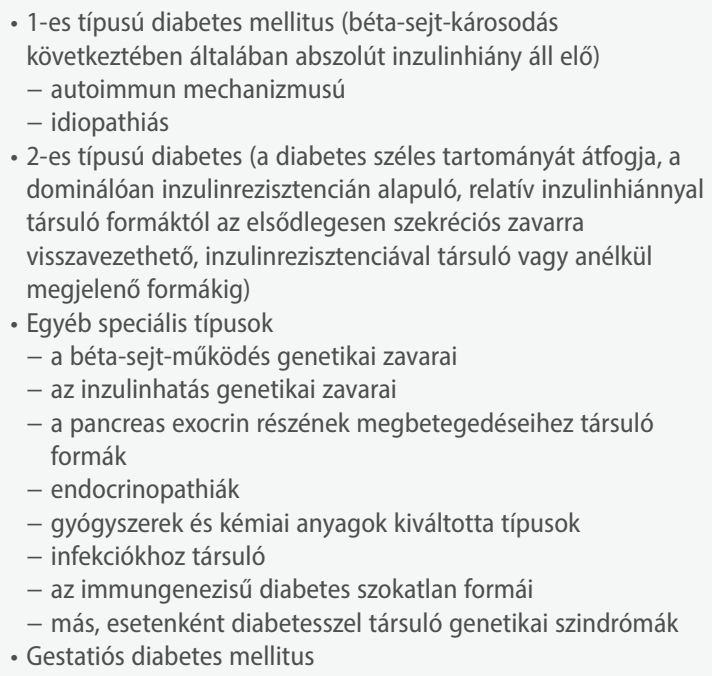

a korábbiakhoz képest jelentős fejlődés az elmúlt évtizedben, az a béta-sejt-múködés genetikai zavarainak, ezen belül is döntően az egy gén mutációjához köthető, ún. monogénes diabetes-formáknak a genetikai azonosítása, ami lehetővé teszi a génmutációhoz adaptált vércukorcsökkentő terápiát, a valóban egyénre szabott, precíziós medicina alkalmazását. ${ }^{4}$ A cukorbetegség típusának meghatározása - és ez alapján a megfelelő kezelés kiválasztása - legtöbbször egyszerűen, a klinikai kép alapján pontosan elvégezhető. Alábbi eseteink bemutatásával a klasszifikáció időnkénti nehézségeire és buktatóira kívánjuk felhívni a figyelmet. A bemutatott esetek mindegyikében megváltozott a cukorbetegség kezelése a klasszifikációt követően.

\section{Első eset}

27 éves sovány nőbeteg, akit három éve GravesBasedow-kór okozta hyperthyreosis miatt kezeltek, és akinél a fenti diagnózis megállapításakor elvégzett orális glukóztolerancia-teszt csökkent glukóztolerenciának (IGT) megfelelő vércukorértékeket mutatott. Három évvel később, a pajzsmirigybetegség reguláris laboratóriumi ellenőrzése kapcsán elvégzett vércukor-szűrővizsgálattal diabetes mellitust állapítottak meg, és gliklazid-kezelést indítottak. E terápia mellett a $\mathrm{HbA}_{1 \mathrm{c}}$-érték $5,27 \%$ volt. A páciens ekkor jelentkezett először klinikánk ambulanciáján.

Bár a betegnek diabetesre utaló klasszikus tünetegyüttese (polyuria, polydipsia, fogyás), illetve ketonuriája soha nem volt, fiatal kora, testalkata, a cukorbetegségre vonatkozó negatív családi anamnézise, de elsősorban az autoimmun eredetű pajzsmirigybetegség jelenléte 1-es típusú diabetes mellitus gyanúját vetette fel. Emiatt éhomi C-peptid-szint és glutaminsavdekarboxiláz elleni antitest (GADA) mérés történt. Az éhomi C-peptid 0,65 ng/ml-es (referenciatartomány: 1,07-3,51 ng/ml) alacsony, a GADA 262,2 U/l-es (referenciatartomány $<2,6 \mathrm{U} / \mathrm{l}$ ), erősen pozitív értéket mutatott. Ezek alapján felállítható volt a T1DM diagnózisa, a klinikai kép alapján annak lassan progrediáló formája (latent autoimmune diabetes in adults, LADA). Ennek megfelelőn a gliklazidot elhagytuk, és napi négyszeri inzulinkezelést kezdtünk. Mára bizonyítottá vált egy 2017-ben publikált metaananalízis alapján, hogy LADA esetén a sulfanylureával történő kezelés nem javasolt! ${ }^{5}$

\section{Buktatók és tanulságok}

A típusmeghatározás buktatója ebben az esetben az volt, hogy a kezelőorvos ,szeme előtt” alakult ki a diabetes, 3 év alatt IGT-ből manifeszt diabeteszszé, és ennek a lassú progressziónak a követése nem szokásos jelenség autoimmun eredetű cukorbetegség esetén. Mivel időben fedezték fel a cukorbetegséget, ezért hiányoztak annak klasszikus tünetei is, amelyek jelenlétét elsősorban az 1-es típusú cukorbetegséghez társítjuk. A tanulság az, hogy társuló autoimmun betegség esetén mindenképpen gondoljunk T1DM lehetőségére! Megjegyzendő, hogy bár a felnőttkori indulású T1DM-ben a szigetsejtellenes autoantitestek közül a GADA előfordulása a leggyakoribb (kb. 60\%-ban pozitív), a GADAnegativitás nem zárja ki a T1DM lehetőségét. ${ }^{6,7}$ Ebben az esetben sokat segít az alacsony C-peptidszint egyidejü jelenléte, a klinikai összkép, vagy ha lehetőség van rá, más szigetsejt-ellenes autoantitestek vizsgálata. Ha valamennyi eddig ismert szigetsejt-ellenes autoantitest vizsgálatára lehetőségünk lenne a rutin gyakorlatban, akkor a T1DM diagnózisakor 98\%-ban találnánk autoantitest-pozitivitást. ${ }^{7}$ 


\section{Második eset}

68 éves férfi, aki $175 \mathrm{~cm}$ magas és $86 \mathrm{~kg}$, 5 éve ismert magasvérnyomás-betegsége. Négy-öt hónapja sokat és gyakrabban vizelt, továbbá szélsőséges mértékű, 35 kg-os fogyásról számolt be. A rendelőben mért vércukorszint $29,6 \mathrm{mmol} / \mathrm{l}$ volt. Klinikai felvétele alkalmával ketonuriát detektáltunk, $\mathrm{HbA}_{1 \mathrm{c}}$-értéke $22,3 \%$ volt! Tekintettel a ketonuriával is társuló, rendkívül rossz szénhidrátanyagcsere-állapotra, folyadékpótlás és átmeneti intravénás inzulinadás után napi négyszeri inzulinkezelést indítottunk. A meglévő klasszikus diabeteses tünetek ellenére a páciens jelenlegi és korábbi testalkata (jelen BMI $28,1 \mathrm{~kg} / \mathrm{m}^{2}$, a fogyás előtti BMI 39,5 $\mathrm{kg} / \mathrm{m}^{2}$ ), valamint a társuló hypertonia T2DM gyanúját is felvetette. Klasszifikáció céljából éhomi C-peptid-szint és szigetsejt-ellenes autoantitest (ICA, szigetsejt elleni citoplazmatikus antitest és GADA) meghatározás történt. A vizsgálatok megtartott C-peptid-szintet (éhomi plazma-C-peptid: $1,07 \mathrm{ng} / \mathrm{ml}$ ) és negatív autoantitest-állapotot (ICA és GADA negatív) mutattak. Előbb napi négyszeri inzulin +metformin, majd metforminnal kombinált orális antidiabetikus terápiára (szitagliptin) tértünk át. 5 évvel később ez utóbbi terápia mellett az éhomi C-peptid-szint 5,81 ng/ml volt (referenciatartomány: 1,07-3,51 ng/ml). 2005-2012 között a $\mathrm{HbA}_{1 c}$-érték 5,78-6,35\% között mozgott, ami feltehetően elsősorban annak köszönhető, hogy a cukorbetegség diagnózisáig kialakult jelentősen kisebb testsúlyt (35 kg-os fogyás) a diabetes kezelése alatt is sikerült megőrizni.

\section{Buktatók és tanulságok}

2-es típusú diabetes mellitus is kezdődhet klaszszikus 1-es típusú diabetesre jellemző tünetekkel, sőt társulhat ketonuriával (akár ketoacidózissal) anélkül, hogy egyéb provokáló betegség jelen lenne! Ilyenkor a teljes inzulinkezelés csak átmeneti, ameddig az anyagcsere rendeződik. Már ebben a periódusban is - ha nincs ellenjavallata - bevezethetjük a metformin-terápiát. A metabolikus helyzet javulása után leépíthetjük az inzulinkezelést és az egyéb, a T2DM-ben alkalmazható terápiás lehetőségek közül választhatunk.

Klinikánkon 2001-2006 között felmértük, hogy a klasszikus tünetekkel felfedezett és ketózissal társuló (ketoacidózis és/vagy ketonuria), újonnan diagnosztizált diabetes mellitus esetek közül $(\mathrm{n}=90)$ hány klasszifikálható T2DM-ként a megtartott éhomi C-peptid (C-peptid a referenciatartományban) és a negatív autoantitest-státusz (ICA és GADA negatív) alapján, ez a szám 22 volt. Tehát a 90 klinikailag - a tünetek és ketonuria/ketoacidózis alapján - T1DM-nek (is) véleményezhető eset közül 68 volt valódi T1DM (66 eset antitest-pozitivitás alapján, 2 esetben negatív volt az antitest-eredmény, de alacsony volt az éhomi Cpeptid-szint). A 22 T2DM-nek klasszifikált esetünk között - 10 éves követés után is - 30\%-ban nem kellett inzulinterápiát alkalmazni. ${ }^{8}$

\section{Harmadik eset}

20 éves nőbeteg, akit hétéves korában hányás miatt vizsgáltak meningitis gyanúval. Az agyhártyagyulladást szerencsére sikerült kizárni, azonban laborértékeiben egy $12 \mathrm{mmol} / \mathrm{l}$-es vércukorszintet észleltek és cukorbetegséget állapítottak meg. Napi egyszeri, bázisinzulin-kezelést indítottak. A beteg 13 éven keresztül részesült napi 5,5 NE humán NPH inzulin terápiában, amely mellett végig kiváló $\mathrm{HbA}_{1 c}$-értékei voltak $(5,9-6,2 \%$ között), stabil vércukorértékekkel, hypoglykaemia-mentesen. Már korábban is felmerült, hogy a beteg cukorbetegsége nem 1-es típusú diabetes. Felnőttgondozásba átkerülve éhomi C-peptidszint- (C-peptid: 2,01 ng/ml, referenciatartomány: 0,80-4,20 ng/ml) és autoantitest-vizsgálat történt (ICA és GADA negatív). Éhomi vércukorszintje a vizsgálat idején emelkedett volt, $8,2 \mathrm{mmol} / \mathrm{l}$-es értéket mutatott. MODY (maturity onset diabetes of the young, azaz fiatalkorban jelentkező, érett típusú cukorbetegség) gyanúja merült fel. Időközben a beteg édesapjánál néhány éve, 40 éves korában 2-es típusú cukorbetegséget diagnosztizáltak, és metformin-kezelést alkalmaztak. Genetikai vizsgálatot javasoltunk. A család (ekkor) a kért vérvételre nem jelent meg, de betegünk igen. Az elvégzett genetikai vizsgálat során egyrészt a glukokináz (GCK) génben (c.623C > T [p.Ala208Val]), másrészt pedig az ABCC8 génben (c.1252T >C [p.Cys418Arg]) találtak mutációt, mindkettőt heterozigóta formában. A GCK gén 6-os exonjában észlelt c.623C > T, p.Ala208Val 
heterozigóta mutáció a szakirodalomban korábban már leírt MODY-t okozó (MODY2 vagy más néven GCK-MODY) patogén eltérés. ${ }^{9} \mathrm{Az}$ ABCC8 génben lévő mutáció patogenitásának megítélése ellentmondásos, leírták diabeteses betegekben és hyperinsulinismusban egyaránt, valamint jelen van a normál populációban is (7 ezrelékes frekvenciával) ${ }^{10,11}$ Már folyamatban volt a beteg genetikai vizsgálata, amikor 15 éves fiútestvérénél szintén cukorbetegséget észleltek. Ekkor történt meg az egész család genetikai vizsgálata, aminek során a 15 éves fiútestvérnél és az édesapánál szintén a GCK gén mutációja okozta MODY2 derült ki (a harmadik testvér és az édesanya genetikai eltérést nem mutatott). Ebben a MODY-formában a cukorbetegség gyógyszeres kezelése legtöbbször nem indokolt. ${ }^{12}$ Természetesen az egészséges életmód tartása ilyenkor is javasolt. Itt jegyezzük meg, hogy mind betegünk (testsúly: $73 \mathrm{~kg}$, testmagasság: 165 cm, BMI: $26,8 \mathrm{~kg} / \mathrm{m}^{2}$ ), mind édesapja túlsúlyos. Páciensünknél - vele egyetértésben - jelenleg elhagytuk az inzulinkezelést.

\section{Buktatók és tanulságok}

Betegünk volt az első eset a családjában, akinél a cukorbetegséget észrevették! A monogénes diabetes-formák esetén a családi halmozódás nyújthat segítséget és vetheti fel a monogénes diabetes lehetőségét. Ebben az esetben erre nem lehetett számítani. Időnként családi halmozódás nélkül is találhatunk monogénes diabetes-formát, de novo mutáció kapcsán. Az eset jól példázza, hogy a diabetes típusba sorolása mennyire - még mindig - az életkor alapján történik: a betegnél 7 évesen észlelt cukorbetegséget T1DM-nek, az édesapánál 40 évesen észrevett diabetest T2DM-nek gondolták, és mindkét esetben ennek megfelelően kezelték. A MODY előfordulása 2-5\%-ra tehető mind az 1-es, mind a 2-es típusúnak gondolt cukorbetegek között. ${ }^{13}$ Ezen diabetes-forma mind a mai napig igen aluldiagnosztizált.

\section{Negyedik eset}

50 éves férfi beteg, akit két éve kezeltek magasvérnyomás-betegséggel. Felvételekor polyuria, polydipsia, szájszárazság és jó étvágy melletti fogyást panaszolt, miután klinikánkra utalták az ügyeleten észlelt $20 \mathrm{mmol} / \mathrm{l}$-es vércukorszint miatt. Érkezésekor vércukra $25,9 \mathrm{mmol} / \mathrm{l}$ volt, ketonuria nélkül, 13,1\%-os $\mathrm{HbA}_{1 \mathrm{c}}$-szint mellett, testsúly: 110 $\mathrm{kg}$, testmagasság: $182 \mathrm{~cm}$, BMI: $33 \mathrm{~kg} / \mathrm{m}^{2}$. Kezelését folyadékpótlással és napi négyszeri inzulinadássall kezdtük. Édesanyját 2-es típusú diabetes miatt „tablettával” kezelték. Bár a beteg cukorbetegsége klasszikus tünetek mellett derült ki (ami általában T1DM-re utal), a társuló hypertonia, a testalkat és az anyai T2DM jelenléte miatt 2-es típusú diabetes gyanúja merült fel bennünk. A felvételt követő reggel ezért C-peptid- és GADA-meghatározásra vérmintát küldtünk. Az első 24 óra eltelte után szokatlan volt, hogy az alkalmazott több mint 100 $\mathrm{NE}$ inzulin/24 óra ellenére a vércukorértékek még mindig $15 \mathrm{mmol} / \mathrm{l}$ felettiek voltak. Ekkor a beteget közelebbről is megtekintve feltűnt, hogy keze/tenyere és lába/talpa nagy, kézujjai vaskosak, fogai között rések vannak és „,tekintélyt parancsoló testalkata” van. Mindezek acromegalia lehetőségére utaltak. Fejfájást, izomgyengeséget, ízületi panaszt illetve egyéb, az acromegaliára jellemző tünetet rákérdezésre sem említett. Látászavara sem volt, bár ez a magas vércukorszint miatt is lehetett volna. Közben megszületett a C-peptid- $(2,64 \mathrm{ng} / \mathrm{ml}$, referenciatartomány: 0,8-4,2 $\mathrm{ng} / \mathrm{ml}$ ) és a GADAeredmény is ( $<5 \mathrm{IU} / \mathrm{ml}$, referenciatartomány: 0-10 IU/ml). Ennek alapján a klasszikus tünetek által sugallt T1DM kizárható volt. Az acromegalia diagnózisát pedig a magas vércukor $(14,3 \mathrm{mmol} / \mathrm{l})$ mellett mért és nem szupprimált növekedésihormon-szint (GH: 15,3 ng/ml, referenciatartomány: 0-6 ng/ml, szupprimált $\mathrm{GH}$ értéke $<0,5 \mathrm{ng} / \mathrm{ml}$ ) és a magas inzulinszerü növekedési faktor-1 (IGF-1: 928,7 $\mathrm{ng} / \mathrm{ml}$, referenciatartomány: $<245 \mathrm{ng} / \mathrm{ml}$ ) bizonyította. A sella MR-vizsgálata hypophysis-microadenomát mutatott. A sikeres hypophysisműtét után, inzulinkezelés nélkül a $\mathrm{HbA}_{1 c}$-érték 5,8\%-os lett, az OGTT vizsgálat emelkedett éhomi vércukorértéken (IFG) kívül egyéb eltérést nem mutatott. A beteg jelenleg metformin-kezelést kap, tekintettel az IFG jelenlétére. A korábbi antihipertenzív kezelést nem lehetett csökkenteni. A beteg családi anamnézise és kövérsége T2DM-re hajlamosító tényező. A jelenleg is észlelhető emelkedett éhomi vércukorszint a T2DM megelőző állapota lehet. A T2DM esetleges kialakulását a kezelt acromegalia nem előzi meg, ehhez egészséges életmód is 
szükséges. Itt jegyezzük meg, hogy adott esetben egy betegnek kétféle eredetű cukorbetegsége is lehet, az elhízás sajnálatos elterjedésével általában a 2-es típusú cukorbetegség színezheti a képet.

\section{Buktatók és tanulságok}

Ebben az esetben a diabetes klasszikus tüneteinek jelenléte 1-es típusú, a családi anamnézis 2-es típusú cukorbetegségre utalt/utalhatott volna. Ugyanakkor az acromegalia - a cukorbetegségen kívül - panaszt nem okozott. A beteg a testalkatváltozásokat magán nem észlelte, kivéve, hogy jegygyürüjét két éve nem tudta felvenni (ezt a panaszt spontán nem említette). Bár felismert endokrin kórképek esetén figyelni szoktuk a szénhidrátanyagcsere alakulását, kevésbé gondolunk a felismert cukorbetegség hátterében lévő esetleges endokrin betegségre. Pedig ebben az esetben (is) lehet lehetőségünk az oki kezelésére.

\section{Összefoglalás}

A diabetes-típus pontos meghatározásához a klinikai kép mellett sokszor szükség van a plazma Cpeptid-szintje és a szigetsejt elleni autoantitestek (legtöbbször ez a GADA mérését jelenti) meghatározására. A C-peptid-szint értékeléséhez mindig szükséges az azonos idejü vércukorszint ismerete, hiszen egy esetleges hypoglykaemia, illetve egy extrém hyperglykaemia befolyásolhatja az endogén inzulintermelést és így a C-peptid-szintet. Újonnan felismert cukorbetegség esetén törekedjünk az etiológiai klasszifikációra, hiszen így van lehetőségünk a legmegfelelőbb kezelés alkalmazására. Amíg nem tudjuk biztonsággal kizárni az 1-es típusú diabetes mellitus lehetőségét, addig inzulinnal kezeljük a beteget, és ne adjunk az inzulinszekréciót serkentő gyógyszert! Ha a klinikai kép T1DM-re utal, de a laboreredmények nem szólnak egyértelműen mellette (antitest-negativitás és a referenciatartományban lévő éhomi C-peptid), akkor is 1-es típusú diabetesnek megfelelő kezelést válasszunk! Ha a cukorbetegség felismerésekor klasszikus tüneteket, esetleg ketotikus állapotot észlelünk, de egyebekben a klinikai kép inkább 2-es típusú diabetes mellitusra utal, akkor szintén a C-peptid mérése és a GADA meghatározása segíti a diabetes típusának eldöntését. Ha a rossz anyagcsere-állapot miatt kezdetben napi többszöri inzulinkezelést indítunk, ez nem jelenti e terápia hosszú távú egyedüli alkalmazását. Végül, ne feledkezzünk meg arról, hogy nemcsak 1-es és 2-es típusú diabetes mellitus létezik! A pontos klasszifikáció soha nem késő, mert ez alapján később is változtathatunk az addigi kezelésen. 


\section{lrodalom}

1. Alberti KGMM, Zimmet PZ, Consultation WHO: Definition, diagnosis and classification of diabetes mellitus and its complications. Part 1: Diagnosis and classification of diabetes mellitus. Provisional report of a WHO consultation. Diabet Med 1998; 15: 539-553. doi:10.1002/(SICI)1096-9136(199807)15:7<539::AID-DIA668>3.0.C0;2-S

2. WHO: Definition, diagnosis and classification of diabetes mellitus and its complications. Report of a WHO consultation. Part 1: Diagnosis and classification of diabetes mellitus. Geneva, 1999. Magyar nyelvü szöveghú fordítása: Diabetologia Hungarica 2000; Suppl 2: 1-28.

3. Egészségügyi Szakmai Irányelv 2017 (Emberi Erőforrások Minisztériuma Egészségügyért Felelös Államtitkárság). Diabetologia Hungarica 2017; 25: $1-83$.

4. Standards of medical care in diabetes - 2017: Summary of revisions Diabetes Care 2017; 40(Suppl 1): S4-S5. doi:10.2337/dc17-S003

5. Buzzetti R, Zampetti S, Maddaloni E: Adult-onset autoimmune diabetes: current knowledge and implications for management. Nat Rev Endocrino 2017; 13: 674-686. doi:10.1038/nrend0.2017.99

6. Pánczél P, Lukács K, Hosszúfalusi N: Diabetes tipizálás a mindennapi gyakorlatban: a precíziós diabetológia első lépései; Diabetologia Hungarica 2017; 5: 339-346. doi:10.24121/dh.2017.27

7. Chiang, Kirkman MS, Laffel LMB, Peters AL: Type 1 diabetes through the life span: a position statement of the American Diabetes Association. Diabetes Care 2014; 37: 2034-2054. doi:10.2337/dc14-1140

8. Barkai LI, Gombos T, Lukács K, Sipter E, Pánczél P, Karádi I, et al.: Ketosis-prone type 2 diabetes among newly diagnosed adult caucasian patients: a follow-up study. Diabetes 2016; 65(Suppl 1): A595-A614. doi:10.2337/db16-2367-2454
9. Osbak KK, Colclough K, Saint-Martin C, Beer NL, Bellanné-Chantelot C, Ellard $S$, et al: Update on mutations in glucokinase (GCK), which cause maturity-onset diabetes of the young, permanent neonatal diabetes, and hyperinsulinemic hypoglycemia. Hum Mutat 2009; 30: 1512-1526. doi:10.1002/humu. 21110

10. Kapoor RR, Flanagan SE, Arya VB, Shield JP, Ellard S, Hussain K: Clinical and molecular characterisation of 300 patients with congenital hyperinsulinism. Eur J Endocrinol 2013; 168: 557-564. doi:10.1530/EJE-12-0673

11. JP Riveline, E Rousseau, Y Reznik, S Fetita, J Philippe, et al.: Clinical and metabolic features of adult-onset diabetes caused by $A B C(8$ mutations. Diabetes Care 2012; 35(2): 248-251. doi:10.2337/dc11-1469

12. Hattersley AT, Patel KA: Precision diabetes: learning from monogenic diabetes. Diabetologia 2017; 60: 769-777. doi:10.1007/s00125-017-4226-2

13. Gat-Yablonski G, Shalitin S, Phillip M: Maturity onset diabetes of the young review. 2006; Suppl 3: 514-520.

Közlésre érkezett: 2018 . december 5.

Közlésre elfogadva: 2019. május 16.

\section{A levelezésért felelös szerzö címe:}

\section{Dr. Kempler Miklós}

Semmelweis Egyetem, III. Belgyógyászati Klinika 1125 Budapest, Kútvölgyi út 4.

E-mail: kemplersoma@gmail.com 